\title{
The Effect of Cinnamon and Clove Powder Compositions on Hair Coloring
}

\author{
Nia Kusstianti, Biyan Yesi Wilujeng, Dindy Sinta Megasari \\ Department of Home Economics \\ Universias Negeri Surabaya \\ Surabaya, Indonesia \\ niakusstianti@unesa.ac.id
}

\begin{abstract}
Hair colouring is a process of colour the white hair due to the ages by colouring certain or all parts of the hair. This research aims to examine the effects of cinnamon and clove powder compositions on the result of the hair colouring. The independent variable applied in this research is the composition of cinnamon and clove powder as X1(1:9), X2 (3:7), X3 (5:5), X4 $(7: 3)$, and X5 (9:1). Moreover, the hair colouring aspects including the colour sharpness and smoothness and hair shine represent the dependent variable and the result of the best in hair colouring is from the panellists. At last, the control variable involves the haircut style with about 15-centimeter lengths for normal hair type, and the bleached hair is at level six. The data collection is done by observation of 5 hair beauty experts and 25 people including lecturers, students, and those who dealt with hair colouring. Further, the data were analyzed by using SPSS in single ANOVA test. The findings showed there was a significant effect of cinnamon and clove powder compositions on hair colouring results based on the aspects of colour sharpness, hair shine, and panellists' preferences. Meanwhile, colour smoothness aspect did not give a significant effect on dealing with the issue. The additional interesting result was based on the Duncan test, $\mathrm{X} 5$ was the best composition to give a significant effect on hair colouring.
\end{abstract}

Keywords-cinnamon; clove; hair colouring.

\section{INTRODUCTION}

Some women who always do hair colouring aim to have beautiful hair. The colouring of hair is performed not only by professionals but also by a popular home cosmetic procedure [1]. Coloring in modern era specifically hair art covers three different processes, such as hair dyeing, hair light tanning, and hair bleaching [2]. Hair colour is one of the cosmetics that can be used in hairstyle to return the original colour or to make other colours. Synthetic oxidative of hair colouring that available in the market contain the combination of peroxide and ammonia that cause the damage to hair and allergic reaction. However, the hair colouring contains the dangerous chemical substances that cause the danger to health and beauty of hair, such as it causes irritation and cancer as the worst effect. Several researchers convey that there was a close interdependence between hair colouring and the rising of cancer patients. It is evidenced in 1994; American Cancer Society and FDA did a research showed that woman who uses black hair colouring for more than 20 years faces a risk of Hodgkin lymphoma and multiple myeloma, cancer that infecting any human bones as similar as leukaemia.

A good hair colouring gives both new colour and nutrition in order to get the healthy hair. The developed oil hair colour can provide multifunctional effects such as become softer, stimulate the hair flexible condition, promote the growth and thickness of the hair, and so on [3]. Thus, nowadays, people tend to use a natural and safe hair colouring without causing the presence of the dangerous illnesses. The substances of hair colouring come from plants and metal. These days, many of plants that can be used for the colouring extraction are classified as medical. In recent studies, it has shown the process of anti-microbial remarkable, anti-fungal, anti-virus activities [4].

Cinnamon (Cinnamomum Verum) is one of the spices that has been used for thousands of years for its enhancement of taste and its potential medical benefits [5]. It is a spice obtained from the inner bark of several tree species from the genus Cinnamomum. Clove (Syzygium Aromaticum) comes from the spruce that classified in Myrtaceae family [6]. Cloves are also a type of spice that is widely used for cooking and herbal medicine. Both cinnamon and clove contain tannins that produce a yellow colour, have a water-soluble characteristic, does not crystallize and mix with proteins from the suspension. A natural hair colouring from cinnamon and clove can be identified from the production of the colour that is a brownish yellow colour.

The author, in this case, conducted a research on making natural hair colouring from cinnamon and clove powder. Based on pre-experimental results, hair colouring applied directly to the hair will become invisible. Therefore, the hair should be bleached the colour, at first, in the sixth level in order to the colour produced from hair colouring can be seen. The first thing to do was applying the cinnamon and clove powder separately to find out the original colour. It found that hair colouring by using cinnamon powder produced the light brown colour and hair colouring by using clove powder produced the dark brown. Hence, in this case, the authors have composed the composition of cinnamon and clove powder as follows; X1 (1: 9), X2 (3: 7), X3 (5: 5), X4 (7: 3) and X5 (9:1) to be tested in 
order to know the resulting of the color. The four compositions are the composition that produces the brightness smoothness colour, hair shine, and the most favoured colour from the panellists. Considering that natural colouring has less strong colouring and unstable, in this case, the researchers add the additional colour known as Mordants. Mordan is mixed with the colouring through a certain process will produce the selected colour. In this case, the type of Mordants used is ferrous sulphate. Ferrous sulphate $\left(\mathrm{FeSO}_{4}\right)$ is a soft white crystal Mordant. It is soluble in water and it produces the smell. Hence, it can be used for the mixing hair colouring.

\section{METHODS}

This study was experimental research using the research design called single factor. Experimental design is the method of conducting informative, time and cost effective tests [7]. The research variables consist of three; 1) The independent variables, the namely composition of cinnamon and clove powder used X1 (1: 9), X2 (3: 7), X3 (5: 5), X4 (7: 3) and X5 (9: 1). 2) The dependent variable is the result of hair colouring aspects such as brightness and smoothness of the colour, hair shine, and the most favoured colour from the panellists. 3) Control variables specifically from the original haircut with a length of hair approximately is $15 \mathrm{~cm}$. The hair used is normal and has been bleached to level six.

The tools, materials and cosmetics used in this research are:

TABLE I. TOOLS IN APPLYING THE HAIR DYES

\begin{tabular}{|c|l|l|c|}
\hline No & Tools & Specification & Amount \\
\hline 1 & Black Bowl & Plastic & 2 pieces \\
\hline 2 & $\begin{array}{l}\text { Comb/brush for } \\
\text { colouring }\end{array}$ & Plastic & 2 pieces \\
\hline 3 & Aluminum Foil & Paper & As needed \\
\hline 4 & $\begin{array}{l}\text { Cylinder } \\
\text { Measurement }\end{array}$ & Plastic & 1 piece \\
\hline 5 & Gloves & Plastic & 2 pieces \\
\hline 6 & Hair Dryer & Iron, Electronic & 1 piece \\
\hline
\end{tabular}

TABLE II. COSMETICS FOR EXPERIMENTS

\begin{tabular}{|c|l|c|}
\hline No & \multicolumn{1}{|c|}{ Materials } & Amount \\
\hline 1 & $\begin{array}{l}\text { Hair dye from cinnamon and clove } \\
\text { powder with different composition }\end{array}$ & @ 10 gram \\
\hline 2 & Shampoo & As needed \\
\hline 3 & Conditioner & As needed \\
\hline 4 & Bleaching Powder & As needed \\
\hline 5 & Developer cream 40 & As needed \\
\hline
\end{tabular}

TABLE III. MATERIALS FOR EXPERIMENTS

\begin{tabular}{|c|l|c|}
\hline No & \multicolumn{1}{|c|}{ Materials } & Amount \\
\hline 1 & A black towel & 5 pieces \\
\hline 2 & Cotton & As needed \\
\hline 3 & Tissue & As needed \\
\hline 4 & Water & As needed \\
\hline
\end{tabular}

The steps of work in the experiment are preparing the tools and materials, the bleaching hair in levels six, mixing colouring substances (cinnamon and cloves powder). Adding $15 \mathrm{ml}$ water as a solvent and then stirring them up, covering the color of the hair that has been bleached and wrapped with aluminium foil. The process needs 60 minutes to execute and check the result. Next, rinse the hair with water and give the hair conditioner. Last, dry it with a towel and a hair dryer until dried out. Apply the steps to five different compositions.

Data collection techniques used are observation methods conducted by 30 observers. Observation is one of the data collection techniques in measuring the interviews and surveying respondents. It is also used to record a phenomenon that occurs in the situation and condition [8]. Criteria assessed in this study include: 1) Color Brightness is the colour that dominates from the colouring of the hair. The colour sharpness is the result of hair colouring of five kinds of composition of cinnamon and clove powder. The results were categorized into five different points; 5: light brown colour, 4: grey, 3: brown, 2: dark grey, 1: blackish brown, 2) Color Smoothness is the colour applied from the base to the whole of the hair. Smooth colour is the result of hair colouring of five compositions of cinnamon and clove powder. The indicators are, 5: very smooth, the color applied on the whole hair, 4: smooth, the color applied from base to center of the hair, 3: fairly smooth, the color applied only on the middle of the hair, 2: less smooth, the color applied only at the end of the hair, 1: uneven smooth, the color does not apply on the whole hair. 3) Hair Shine is the colour reflection of light on the hair colouring. The hair that is classified as a dull hair, it is unable to produce the shine because the cuticle has been damaged. Hair shine is the result of five compared compositions of cinnamon and clove powder hair colouring. The indicators are 5: very shiny, not dull; 4: shiny, not dull; 3: simply shiny, not dull; 2: less shiny, a bit dull; 1: not shiny, dull. 4) The Level of Panelists' Preferences is the most preferred colour among the five compositions of hair colouring. The preferred level is the result of hair colouring of five different compositions of cinnamon and clove powder. The indicators are, 5 points are for likes the most, 4 points are likes, 3 points are enough, 2 points are less like, and 1 point is disliked.

The data analysis technique is single ANOVA using SPSS version 13. The analysis of variance (ANOVA) is widely used a statistical test. It is used to analyze differences among three or more groups [9]. If the result shows no real effect then Duncan test is recommended. Duncan's multiple range test is used to show the significance level of the variables [10]. 


\section{RESULTS AND DISCUSSION}

\section{A. Color Brightness}

The average values of hair brightness on the composition of cinnamon and clove powder resulted in the composition of X5, 9 grams of cinnamon powder and 1 gram of clove powder had the highest average value of 4.8333 . The compositions of $\mathrm{X} 4,7$ grams of cinnamon powder and 3 grams of clove powder had an average value of 4.0000 . The composition of X3, 5 grams of cinnamon powder and 5 grams of clove powder had an average value of 3.0000. The compositions of X2, 3 grams of cinnamon powder and 7 grams of clove powder had an average value of 2.6333. The lowest average values were $\mathrm{X} 1,1$ gram of cinnamon powder and 9 grams of clove powder with an average value of 1.5667 .

The result of analysis of single ANOVA on colour brightness average of cinnamon and clove powder obtained the value of $\mathrm{F}=58.151$ showed significant at $0.000(<0.05)$. Hence, it can be interpreted that the influence of the composition of cinnamon and clove powder to hair colouring result was at the brightness of colour.

The Duncan test result showed a significant difference for the composition of cinnamon and clove powder to the hair colouring results on the colour brightness among X1 (1: 9) X2 (3: 7) X3 (5: 5) X4 (7: 3) ) and X5 (9: 1). The best colour outlook is on the composition of X5, 9 gram of cinnamon powder and 1 gram of clove powder.

\section{B. Color Smoothness}

The average value of the colour smoothness on the composition of cinnamon and clove powder to the hair colouring achieved the highest value of 3.8667 that was the composition of X5, 9 grams of cinnamon powder and 1 gram of clove powder. The composition of X1, 1 gram of cinnamon powder and 9 grams of clove powder had 3.8333 values. The composition of $\mathrm{X} 4,7$ grams of cinnamon powder and 3 grams of clove powder had a value of 3.7333. For the composition of $\mathrm{X} 2,3$ grams of cinnamon powder and 7 grams of clove powder and X3, 5 grams of cinnamon powder and 5 grams of clove powder got the same value that was 3.7000 .

The result of single ANOVA analysis on the average of colour smoothness of cinnamon and clove powder achieved the value of $\mathrm{F}=0.225$ which was not significant at 0.924 (not $<0.05$ ). It meant that there was no significant difference in composition of cinnamon and clove powder to colour smoothness. It can be concluded that all compositions got an average value of three that the hair colouring was smooth on all hair-colouring compositions.

Duncan test showed there was no significant difference in the composition of cinnamon and clove powder to hair colouring resulted on hair smoothness among X1 (1: 9) X2 (3: 7) X3 (5:5) X4 (7:3) and X5 (9:1).

\section{Hair Shine}

The results of colouring with the best hair shine of X5, 9 grams of cinnamon powder and 1 gram of clove powder had an average value of 3.7667. The composition of X4, 7 grams of cinnamon powder and 3 grams of clove powder had a value of 3.6333. The compositions of $\mathrm{X} 3,5$ grams of cinnamon powder and 5 grams of clove powder had a value of 3.000. The compositions of X2, 3 grams of cinnamon powder and 7 grams of clove powder had a value of 2.9000 . The compositions of $\mathrm{X} 1,1$ gram of cinnamon powder and 9 grams of clove powder got the lowest value with 2.8333 .

The results of single ANOVA average shine of the composition of cinnamon and clove powder achieved $\mathrm{F}=$ 5.846 significant $0.000(<0.05)$. This can be interpreted that there was the influence of the composition of cinnamon and clove powder on the results of hair colouring on the shine of hair.

Based on the Duncan test, there was a significant difference between the cinnamon and clove powder on the hair coloring result of the hair shine among X1 (1:9) X2 (3: 7) X3 (5: 5) composition with X4 (7:3) and X5 (9:1).

\section{The Result of Panelists' Preferences}

The average value of the panellists' preference level of the composition of cinnamon and clove powder obtained the best average of X5, 9 grams of cinnamon powder and 1 gram of clove powder had a value of 4.3333 . The compositions of X4, 7 grams of cinnamon powder and 3 grams of clove powder had a value of 3.9667. The compositions of X3, 5 grams of cinnamon powder and 5 grams of clove powder had a value of 3.8667. The compositions of X1, 1 gram of cinnamon powder and 9 grams of clove powder. The composition of the lowest value of $\mathrm{X} 2,3$ grams of cinnamon powder and 7 grams of clove powder.

The result of single ANOVA analysis on the average of panellists' preference level of the composition of cinnamon and clove powder to the hair colouring result obtained $\mathrm{F}=1.585$ value which was not significant 0.181 (not $<0.05$ ). This can be interpreted that there was no influence of composition cinnamon and clove powder to the hair colouring result at panellists' preference level.

Duncan test showed a significant difference between the composition of cinnamon and clove powder to the hair colouring result at panellists' preferences among X1 (1: 9) X2 (3: 7) X3 (5: 5) with X4 (7: 3) and X5 (9: 1). The highest preference level value on the composition of X5, 9 grams of cinnamon powder and 1 gram of clove powder.

\section{E. The Best Composition}

Based on the aspects of the assessment criteria of brightness, smoothness, hair shine and panellist preferences. $\mathrm{X} 5$ compositions got the highest score. Thus, the best composition of the four criteria based on the observers' assessment was the composition of X5, 9 grams of cinnamon and 1 gram clove.

\section{CONCLUSION}

Based on the statistical analysis results, there was the influence of the composition of clove and cinnamon powder to the results of colour brightness, hair shine and panellists' 
preferences, but there was no influence of the composition of cinnamon and clove powder to the colour smoothness.

The best composition based on colour brightness, hair shine, colour smoothness and panellists' preferences was X5, 9 grams of cinnamon powder and 2 grams of clove powder. The colour resulted was light brown.

\section{REFERENCES}

[1] Dharmisatha Patel, Salara Narayana, Bhuvana Krishnaswamy, "Trends in Use of Hair Dye: A Cross-Sectional Study", Int J Trichology, 2013 Jul-Sep; 5(3): 140-143.

[2] Rostamailis, dkk.2008.Tata Kecantikan Rambut jilid III.Jakarta : Macanan Jaya Cemerlang.

[3] Z. Shahi, M. Khajeh Mehrizi, M.Hadizadeh, "AReview of Natural Resources Used to Hair Color and Hair Care Products", Journal of Pharmaceutical Sciences and Research, Vol. 9(7), 2017, 1026-1030.
[4] Kate Wells, "Colour, health and wellbeing: The hidden qualities and properties of natural dyes", Journal of the International Colour Association (2013): 11, 28-36.

[5] Singletary, Keith, "Cinnamon : Overview of Health Benefits", Food and Nutrition, Volume 43 - Issue 6 - pp 263-266.

[6] Manuela Baietto, "Bud Fall Induction in Clove (Syzygium Aromaticum), Academic Research International, Vol. 5(4) July 2014.

[7] Marit Risberg Ellekjaer, Soren Bisgaard, "The use of experimental design in the development of new products", International Journal of Quality Science, Vol. 3 Issue: 3, pp.254-274.

[8] Uma Sekaran, 2006, "Metodologi Penelitian Untuk Bisnis", Jakarta : Salemba Empat.

[9] Ugur Kucukj, Mehmet Eyuboglu, Hilal Olgun Kucuk, Gikhan Degirmencioglu, "Importance of using proper post hoc test with ANOVA", International Journal of Cardiology 209 (2016) 346.

[10] Asha Ramteke, SK Khanuja, OP Chandrakar, Tapesh Gupta, "Survival Benefits Dominate the Whole Life Risk Coverage Among The rural Population of RaipurPostal Division of Chhattisgarh State", International Journal of Research Science \& Management, 3 (5): May, 2016. 